\title{
Identifying the Drivers of Economic Globalization and the Effects on Companies' Competitive Situation
}

\author{
Knut Erik Bang and Tore Markeset \\ University of Stavanger, N-4036 Stavanger, Norway \\ \{knut.e.bang, tore.markeset\}@uis.no
}

\begin{abstract}
Globalization has changed the world. This paper aims to contribute to the understanding of how companies' competitive situation is affected by globalization. The paper identifies the main drivers of economic globalization and categorizes the effects into size effects, location effects and pressure effects. Size relates to the magnitude of the potential competition. Location relates to the potential impact on a company's activities in terms of what to do where and by whom. Pressure effects are the ones that are related to competitive pressure.
\end{abstract}

Keywords: Economic globalization, outsourcing, offshoring, value chain fragmentation, company competition.

\section{Introduction: Globalization, Effects and Company Competition}

Globalization has changed the world and the competitive situation of companies, and has affected us as individuals. The objective of this study is to contribute to the understanding of how globalization affects the competitive environment of companies. The drivers and effects from globalization are identified and defined, and their impact on the forces of competition evaluated.

A review of existing literature was carried out to identify a list of the main drivers of the economic globalization, and to establish the main effects from these drivers that are relevant in terms of affecting the competitive situation for companies. The approach focused on the impact on Michael Porter's [1] model of the competitive situation and on the value chain.

\subsection{Globalization as a Process}

The term 'globalization' is used in literature in a variety of settings and contexts to account for a number of different things. According to Stiglitz [2], the phenomenon of globalization encompasses the international flow of ideas and knowledge, the sharing of cultures, global civil society and the global environmental movement. Steger [3] separates globalization into four dimensions, namely economic, political, cultural and ecological. However, he stresses that the dimensions are overlapping and interconnected. For the objective of investigating the effects of globalization on companies' competitive situation, we will limit our use of the term to economic globalization, 
which according to Stiglitz [2] entails the closer economic integration of the countries of the world through the increased flow of goods and services, capital and labor.

Another necessary limitation and clarification arises from the fact that, according to Steger [3], the term 'globalization' is used to describe a process, a condition, a force, a system and an age. We choose here to use the term 'globalization', in accordance with Ellwood [4], to be the process of accelerating integration of the global economy. The process is characterized by movement toward greater interdependence and integration [3].

By defining globalization as a process, we have defined it to be something that brings us from one state to another [3]. Globalization is ongoing, indicating that the process will continue and that we have not reached the end state yet, though our economies and markets have come to be marked by the process and are molded toward the end state. We therefore define globalized markets as markets that have become significantly marked by the integration of the global economy, not ones that have come to an end state of globalization. Similarly, we define globalized economies as economies that have become significantly marked by the integration of the global economy. Defining globalization as an accelerating process signals an expected intensified movement in this direction.

\subsection{Porter's Model of Competition}

Harvard professor Michael Porter's model of the five forces on competition [1] (see Figure 1) has become one of the most established approaches to view competition. It can be used for industry competition or for a company's place within an industry competition. With the introduction of the model of the five forces of competition, Porter lifted the view on competition from being focused on the rivalry between competitors in an industry to include a number of other potential competitors: the suppliers through their bargaining power, the buyers of the industry's products through their bargaining power, the potential threat from new entrants to the industry competition, and finally the threat of substitutes through their potential to take market shares from the industry. The model thus introduced a new dynamic situation where players from all these forces over time are potential competitors, instead of a previously more static picture focused on the existing rivals.

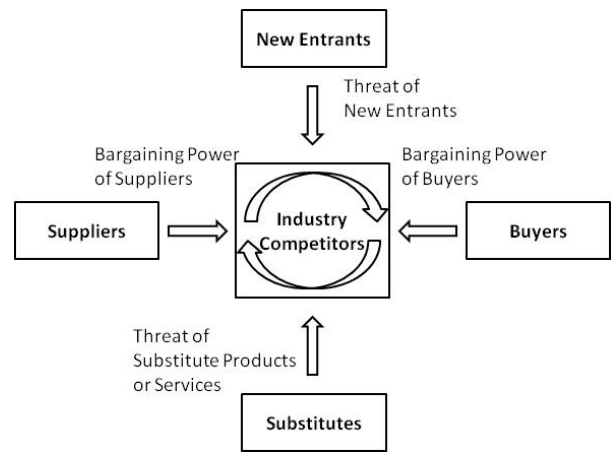

Fig. 1. The five forces of competition [1] as represented in [5] 
However, to be able to assess the impact of globalization on the competitive situation, we will also need to address another of Porter's concepts, namely the value chain [5]. The value chain offers a view of a company as a set of interlinked activities. Porter argues for the necessity of addressing the strategic choices for the individual activities to gain competitive advantage. The activities in the model are shown either as sequential, as part of the production process, or as support activities. The model is shown in Figure 2.

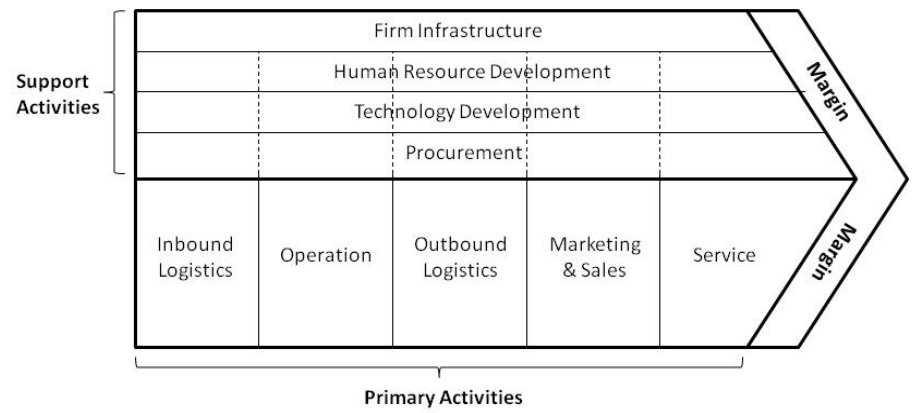

Fig. 2. The value chain from Porter (1985)

The question formed here is: What are the drivers and effects of globalization that affect the model of the five forces of competition? To evaluate this, we start by investigating what the literature on the subject has to say on what are the different drivers and the effects of these.

\section{Drivers of Globalization}

It is emphasized that in the evaluation of drivers of globalization the focus is on the ones that are considered to have a significant effect on the competitive situation of companies. Politics and social factors are major forces behind globalization (e.g. [2], [6], [7], [8], [9]) and have led to the reduction of trade barriers and economic reforms, paving the way for economic integration. Stiglitz [2] claimed that politics shaped globalization. In this evaluation it is considered a predecessor event and omitted.

In evaluating the effects of globalization, it can be useful to separate drivers and effects, though both can affect the competitive situation of a company. The drivers of globalization are the forces that lead towards closer economic integration. Rather than setting up a comprehensive list, the paper focuses on the factors mentioned most in the literature. These can be summarized as:

- Lower trade barriers

- Lower transportation costs

- Lower communication costs

- Information and communication technology (ICT) development

- Spread of technology 


\subsection{Lower Trade Barriers}

Lower trade barriers are recognized as one of the main drivers. The International Monetary Fund (IMF) [10] states that the expansion of world trade through the elimination or reduction of trade barriers, such as import tariffs, is a core element of globalization. Lowering trade barriers involves more than just reducing import tariffs; the IMF further mentions openness to foreign technology, investments (especially foreign direct investments), and a participation in - and integration with - the global economy. Defined this way, the lowering of trade barriers includes the attaching of national economies to global trade, as has gradually happened with India and China. (See e.g. [6] and [8]).

\subsection{Lower Transportation Costs}

Lower transportation costs and lower communication costs are described by Stiglitz [2] as the main parts of economics that are driving globalization. Lower transportation costs enable products manufactured far from the market to become more competitive. Rubin [11] demonstrates how changes in fuel and transportation costs act the same way as changes in import tariffs on products manufactured far from the market. Reduced transport costs have enabled the world markets and economies to become more linked together and integrated.

\subsection{Lower Communication Costs}

The same applies to communication costs. The costs of international or overseas phone calls have been reduced significantly over the last two decades. According to Friedman [6], the massive investment in IT-infrastructure, especially fiber optic cables, up to the dot.com bust in 2001 and the subsequent lowering of data transfer cost to practically zero was one of the main drivers of globalization.

\subsection{Information and Communication Technology Development}

It is not just the cost of communication that has improved; it is the whole way we communicate and interact. Over the last two decades we have seen the internet evolve and spread as a source of information as well as a tool for communication. The latter is shown in terms of e-mails taking over from normal post, cheaper solutions for phoning, video conferencing, massive amount of data transfer and so on. Friedman [6] further points to the evolution of shared work platforms that enable people from different locations to work together on the same project as one of the things that have a significant effect on how we work and share work between locations. Milberg and Winkler [12] note that the progress in electronic communication has enabled the massive expansion of international supply chains, that again lead to more foreign investments and aligning with foreign suppliers, creating the potential for cost reductions.

\subsection{The Spreading of Technology}

The potential from the developments in information and communication technology could not be achieved if not for the widespread use of the technology. Former HP 
CEO, Carly Fiorina (cited in [6]), described how everything from photography, word processing, architectural drawings to home appliances are being digitized and can be transmitted, shaped and manipulated from other locations wirelessly on a computer or by handheld devices like PDAs or cell phones. The digitization thus plays its part in globalizing the world, but without the spread of the technology to link to this information (PCs, PDAs, smartphones, iPads and so on), the digitization would not help much. James [13] argues that much of the difference in growth patterns in the developing world comes from exactly this: the difference in the spread of information technology. Manufacturing and production technologies are other enabling technologies that are spreading [14], and access to technological progress gathers speed. The spread of technology, whether in the form of information technology or for manufacturing or agriculture, is as important as its development in the first place and is considered a driver of globalization.

\section{Effects of Globalization}

The literature study further identified numerous effects of globalization in various areas. These effects were evaluated in terms of which could influence the competitive situation of companies. The ones that had an influence were grouped according to how they could influence the situation. The effects of globalization on companies' competitive situation have therefore been grouped under three headings: size, location and pressure. Size covers the factors of larger market potential, larger numbers of potential clients, larger numbers of potential competitors, and larger numbers of potential suppliers and co-operating partners. Location covers disaggregation of value chains, offshoring, outsourcing, and complex supply chains. Pressure covers cost and price pressure, higher rates of change, more diverse markets, lower start-up barriers, and lower visibility.

\subsection{Size Effects}

The market in which a company is competing is no longer one or a group of regional geographically isolated markets. According to a study by Harvard University ([15] cited in [6]), "the global economic world" in 1985 consisted of North America, Western Europe, Japan and parts of Latin America, Africa and the countries of East Asia, and the total population of this area participating in international trade was about 2.5 billion people. By 2000 the former Soviet Union, India and China had joined the global economy and its population had expanded to 6 billion people. As the trade barriers have come down, most of the globe acts more like one single market. That does not imply that it is one homogenous market place, but that the markets are being linked together, hurdles that prevented foreign competition have gradually been reduced and that it is possible for others to enter. The national markets may be diverse, but the market potential for products and services is to a large extent now global not local. This means that for an individual company's or an industry's products and services, the market potential is larger where previously there was segmentation through limitations in the geographical reach of the industry boundary. As a natural consequence of the increasing total market, so the number of potential clients, number of 
potential competitors, and the number of potential suppliers and co-operating partners also increase. The literature has focused more on the increased competition (e.g. [16], [7] and [17]) than on increased markets and the potential and challenges related to suppliers and co-operating partners.

\subsection{Location Effects}

Location addresses the globalization effects that have a potential impact on a company's activities: what activities to do where and by whom. Fragmentation of the production process has become a major theme in international economics research (e.g. [18], [19], [20], [21]). Krugman [22] referred to this phenomenon as "slicing up the value chain" and argued 16 years ago that this is one of the major trends in international trade, resulting in higher growth in trade than in the underlying growth in value-adding or the gross domestic product (GDP) of countries. This higher trade growth comes from the increased options of locations across borders for the value-adding of the different slices of the value chain resulting from lower barriers for the flow of goods, capital and technology. Exploiting these options is normally termed 'offshoring' and has become another major theme in research (e.g. [23], [12]). Offshoring may be defined as transnational relocation or dispersion of activities in line with Doh et al. [24]. Some of these relocations of activities across borders happen within the firm by setting up their own facilities, normally termed Foreign Direct Investment (FDI), and some of the relocations happen in the form of outsourcing to other companies.

For the last 20 years there has been a general trend in corporate restructuring to concentrate on the core activities and outsourcing of a range of business functions [25]. For firms that they studied, Mudambi and Venzin [23] noted that "the magnitude of offshoring appears to be increasing for all firms. However, the magnitude of outsourcing is not uniform." This implies that while companies continue to relocate activities to low-cost countries, the setting of firm boundaries varies. Lau and Zhang [26] find that the main economic factors of outsourcing are cost reduction, cost savings and reduction in capital investment. Levy [27] argues that what has enabled these latest forms of offshoring and outsourcing is "the increased organizational and technological capacity of companies, particularly multinational companies, to separate and coordinate a network of contractors performing an intricate set of activities." These increasingly more complex supply chains "are playing an increasingly crucial role in the competitiveness of companies and national economies" [28].

\subsection{Pressure Effects}

The last grouping of factors is related to competitive pressure. Liemt [29] states that "economic globalization has intensified competitive pressures." The increased pressure comes along several axes at the same time. Cost and price pressure has increased (e.g. [30], [20]) as a result of the new openness of economies. The pressure to cut costs in order to stay competitive acts in a loop so as to put increased pressure on further offshoring and outsourcing of activities, and also on further specialization or fragmentation of the value chain. There is also a higher rate of change in a company's competitive environment (e.g. [7], [6]). The higher rate of change relates to product cycles, production technology, competitors and customer preferences. Another factor 
that adds to the pressure is the added diversity of the market (e.g. [16]). With industry boundaries changing to becoming global, added complexity comes from the diversity within this new larger market. Competitors can have a larger global potential, but to achieve it this added diversity must be addressed, and companies that are better at it will gain a competitive advantage. The spread of technology and information has also led to lower start-up barriers for setting up companies (e.g. [6]). Another factor that relates to the model is lower visibility. In a regional geographic market prior to globalization, a medium-sized company could have a relatively good overview of its competitive situation. We can visualize this by a pie chart where white represents the known part, black the unknown, and gray the 'hinted' part which is suspected or on which some partial knowledge exists. The expansion from regional to global then can be represented as in Figure 3. In the new markets it is generally more difficult to get an overview, and it might be impossible to get the full picture. This representation can be used on all the different parts of the competition model, to represent the direct competition, potential buyers and suppliers alike.

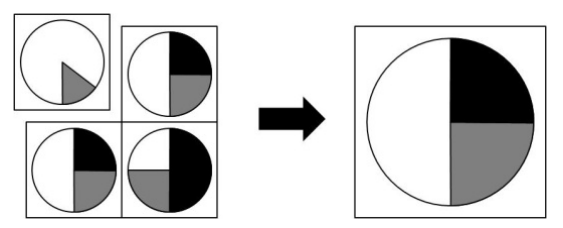

Fig. 3. Reduced visibility in the integrated market (white representing known, gray representing partly known, and black representing the unknown part of the competitive situation)

\section{Concluding Remarks}

Based on a literature study, the main drivers of economic globalization that affect the competitive situation have been identified to be lower trade barriers, lower transportation costs, lower communication costs, ICT development and the spread of technology. These have a number of effects that have been grouped into the areas of size, location and pressure according to how they influence the competitive situation as shown in Figure 4.

\begin{tabular}{|c|c|c|c|}
\hline Drivers & Effects: Size & Effects: Location & Effects: Pressure \\
\hline Lower trade barriers & Larger market potential & $\begin{array}{l}\text { Fragmented value } \\
\text { chains }\end{array}$ & $\begin{array}{l}\text { Cost and price } \\
\text { pressure }\end{array}$ \\
\hline $\begin{array}{c}\text { Lower transportation } \\
\text { costs } \\
\end{array}$ & $\begin{array}{l}\text { Larger number of } \\
\text { potential clients }\end{array}$ & Offshoring & Higher rate of change \\
\hline $\begin{array}{c}\text { Lower } \\
\text { communication costs }\end{array}$ & $\begin{array}{l}\text { Larger number of } \\
\text { potential competitors }\end{array}$ & Outsourcing & More diverse markets \\
\hline ICT development & $\begin{array}{l}\text { Larger no. of potential } \\
\text { suppliers and partners }\end{array}$ & Complex supply chains & Lower start-up barriers \\
\hline Spread of technology & & & Lower visibility \\
\hline
\end{tabular}

Fig. 4. The drivers and effects from globalization affecting the competitive situation 
The size effects relate to the fact that as the markets of the world comes closer together, the market potential for individual companies increase several-fold, but the number of potential competitors increases too. Larger number of potential customers increases the potential, but also the complexity.

Location effects relate to the increased fragmentation of value chain into smaller and more standardized activities, and to the increased use of outsourcing and/or offshoring to relocate activities to the outside of the company or to other low cost countries.

Pressure effects relate to the factors that increase the pressure on the competitive situation. These include a higher cost and price pressure, higher rate of change, more diverse markets, lower start-up barriers and lower visibility. Higher rate of change can include rate of change for products (shorter product cycles) changes to production technology or changes in competitors. The competitive situations of companies are changing at an unprecedented rate.

\section{References}

1. Porter, M.E.: How Competitive Forces Shape Strategy. Harvard Business Review, 137-145 (March/April 1979)

2. Stiglitz, J.E.: Making Globalization Work. Norton \& Company, Inc., New York (2006)

3. Steger, M.B.: Globalization: A very short introduction. Univ. Press, Oxford (2009)

4. Ellwood, W.: The No-Nonsense Guide to Globalization, 2nd edn. New Internationalist, Oxford (2006)

5. Porter, M.E.: Competitive Advantage: Creating and Sustaining Superior Performance. The Free Press, New York (1985)

6. Friedman, T.L.: The World is Flat: A Brief History of the Twenty-First Century. Farrar, Straus and Giroux, New York (2005)

7. Sirkin, H.L., Hemerling, J.W., Bhattacharya, A.K.: Globality: Competing with Everyone from Everywhere for Everything. Business Plus, New York (2008)

8. Meredith, R.: The Elephant and the Dragon: The Rise of India and China and What It Means for All of Us. W.W. Norton \& Company, Inc., New York (2007)

9. Goldin, I.: Globalization and Risks for Business: Implications of an Increasingly Interconnected World. Lloyd's $360^{\circ}$ Risk Insight (2010), http://www. lloyds.com/360 (acc. December 19, 2010)

10. IMF: Globalization: A Brief Overview. IMF Issue Brief, No. 02/08 (2008), http: / / www .imf. org (acc. December 19, 2010)

11. Rubin, J.: Why Your World Is About to Get a Whole Lot Smaller: Oil and the End of Globalization. Random House, Toronto (2009)

12. Milberg, W., Winkler, D.: Globalization, Offshoring and Economic Insecurity in Industrialized Countries. DESA Working Paper, No. 87 (2009)

13. James, J.: Information Technology, Cumulative Causation and Patterns of Globalization in the Third World. Review of International Political Economy 8(1), 147-162 (2001)

14. Easterbrook, G.: Sonic Boom: Globalization at Mach Speed. Random House, NY (2009)

15. Freeman, R.B.: Doubling the Global Work Force: The Challenge of Integrating China, India, and the Former Soviet Bloc into the World Economy. Peterson Institute of International Economics (2004), http://www.iie.com/publications/ papers / freeman1104 .pdf (acc. July 18, 2011) 
16. Agtmael, A.: The Emerging Markets Century: How a New Breed of World-Class Companies is Overtaking the World. Simon \& Schuster UK Ltd., London (2007)

17. Teagarden, M.B., Cai, D.H.: Learning from Dragons who are Learning from us: Developmental Lessons from China's Global Companies. Organizational Dynamics 38(1) (2009)

18. Defever, F.: Functional Fragmentation and the Location of Multinational Firms in the Enlarged Europe. Regional Science and Urban Economics 36, 658-677 (2006)

19. Hummels, D., Ishii, J., Yi, K.M.: The Nature and Growth of Vertical Specialization in World Trade. Journal of International Economics 54, 75-99 (2001)

20. Burda, M.C., Dluhosch, B.: Cost Competition, Fragmentation, and Globalization. Review of International Economics 10(3), 424-441 (2002)

21. Macher, J.T., Mowery, D.C.: Vertical Specialization and Industry Structure in High Technology Industries. Advances in Strategic Management 21, 317-355 (2004)

22. Krugman, P.: Growing World Trade: Causes and Consequences. Brookings Papers on Economic Activity (1), 327-377 (1995)

23. Mudambi, R., Venzin, M.: The Strategic Nexus of Offshoring and Outsourcing Decisions. Journal of Management Studies 47(8), 1510-1533 (2010)

24. Doh, J.P., Bunyaratavej, K., Hahn, E.: Separable But Not Equal: the Location Determinants of Discrete Services Offshoring Activities. Journal of International Business Studies 40, 926-943 (2009)

25. Flecker, J.: Outsourcing, Spatial Relocation and the Fragmentation of Employment. Competition and Change 13(3), 251-266 (2009)

26. Lau, K.H., Zhang, J.: Drivers and Obstacles of Outsourcing Practices in China. Int. Journ. of Physical Distribution \& Logistics Management 36(10), 776-792 (2006)

27. Levy, D.L.: Offshoring in the New Global Political Economy. Journal of Management Studies 42(3), 685-693 (2005)

28. Hameri, A.P., Hintsa, J.: Assessing the Drivers of Change for Cross-Border Supply Chains. Int. J. of Physical Distr. and Logistics Management 39(9), 741-761 (2009)

29. Liemt, G.: Economic Globalization: Labour options and Business Strategies in High Labour Cost Countries. International Labour Review 131, 453-470 (1992)

30. Ross, A.: Fast Boat to China: High-Tech Outsourcing and the Consequences of Free Trade Lessons from Shanghai. Pantheon Books, New York (2006) 